\title{
多軸鍛造を施した $\mathrm{Al}-\mathrm{Al}_{3} \mathrm{Ti}$ 複相材料の $\mathrm{Al}_{3} \mathrm{Ti}$ 粒子分布に及ぼす 鍛造温度の影響
}

\author{
佐藤 尚**手島 史貴**.渡辺 義見*
}

Journal of The Japan Institute of Light Metals, Vol. 68, No. 1 (2018), 2-8

(C) 2018 The Japan Institute of Light Metals

\section{Effects of forging temperature on $\mathrm{Al}_{3} \mathrm{Ti}$ particle distribution in $\mathrm{Al}-\mathrm{Al}{ }_{3} \mathrm{Ti}$ multi-phase materials deformed by multi-directional forging}

\author{
Hisashi SATO* ${ }^{*}$, Fumitaka TESHIMA** and Yoshimi WATANABE*
}

\begin{abstract}
The effects of forging temperature on the distribution of $\mathrm{Al}_{3} \mathrm{Ti}$ platelet particles in $\mathrm{Al}-\mathrm{Al}_{3} \mathrm{Ti}$ multi-phase materials deformed by multi-directional forging (MDF) are investigated. The $\mathrm{Al}-\mathrm{Al}_{3} \mathrm{Ti}$ multi-phase materials consist of large $\mathrm{Al}_{3} \mathrm{Ti}$ platelet particles and $\alpha$ - $\mathrm{Al}$ matrix. The MDF is performed at either room temperature (RT) or $573 \mathrm{~K}$, and the $\mathrm{Al}_{3} \mathrm{Ti}$ platelet particles are refined at both temperatures. The refined particles in the specimen subjected to MDF at $573 \mathrm{~K}$ are larger than those in the specimen subjected to MDF at RT. This size difference can be explained by dynamic recrystallization of the $\alpha$-Al matrix during MDF. Furthermore, the change in the spatial distribution of the refined $\mathrm{Al}_{3}$ Ti particles in the forged specimens is evaluated using Morishita's index. Based on the results, it is found that the spatial distribution of the particles changes depending on the plastic flow of the $\alpha$-Al matrix during MDF. In addition, the change in spatial distribution of the particles is greater when MDF is carried out at RT than at $573 \mathrm{~K}$. Therefore, it is concluded that the size and spatial distributions of the $\mathrm{Al}_{3}$ Ti platelet particles in the $\mathrm{Al}-\mathrm{Al}_{3} \mathrm{Ti}$ multi-phase materials deformed by the MDF depend on the forging temperature.
\end{abstract}

(Received May 1, 2017 Accepted September 8, 2017)

Keywords: composite; severe plastic deformation; multi directional forging (MDF); particle distribution; Morishita's index

\section{1. 緒言}

第 2 相粒子を有する金属基複相材料に巨大ひずみ加工を施 すと，母相の結晶粒微細化や母相の大きな塑性流動に起因し た第2相粒子の破壊が生じる ${ }^{1) \sim 14)}$ 。特に，複相材料中の第 2 相粒子分布は材料強度に大きく寄与するため, 複相材料への 巨大ひずみ加工に伴う母相の変形挙動と第 2 相粒子の分散状 況の変化（以降, 分散挙動と呼ぶ）を関連づけることは重要 である。

これまで，巨大ひずみ加工に関する研究は，主に第2相粒 子を持たない金属材料の結晶粒微細化挙動についてなされ

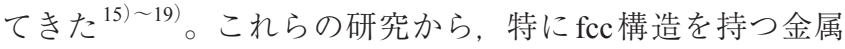
材料への巨大ひずみ加工に伴う結晶粒微細化は grain subdivision 機構によって生じることが明らかになっている ${ }^{17), 19) 。 ~}$ 一方, 複相材料への巨大ひずみ加工に関する研究では, 加 工に伴う第 2 相粒子の空間分布の変化について多く報告が なされている ${ }^{1) \sim 5), 7), 10) 。 S a b i r o v ら は ， A 6061 ア ル ミ ニ ウ ム ~}$ 合金母相中に粒状の $\mathrm{SiC}$ （直径 $0.3 \sim 1 \mu \mathrm{m}$ ） が分散した6061$10 \mathrm{vol} \% \mathrm{SiC}$ 複相材料に高圧ねじり加工（High Pressure Torsion:
$\mathrm{HPT}$ を施し, HPTに伴う $\mathrm{SiC}$ 粒子の空間分布の変化につい て調べた ${ }^{5)}$ 。この複相材料は, $\mathrm{SiC}$ 粒子が密集してクラスター を形成しながら母相中に分散した組織を有する。その結果, HPT 後の複相材料における $\mathrm{SiC}$ 粒子は, クラスターを形成 せずに母相に均一分散することを明らかにしている。一方， Köhlerらは, 直径 $0.2 \sim 2 \mu \mathrm{m}$ の粒状 $\mathrm{Al}_{2} \mathrm{O}_{3}$ 粒子が分散した $\mathrm{Al}-$ $\mathrm{Al}_{2} \mathrm{O}_{3}$ 複相材料に押出加工を施すと, 母相中の $\mathrm{Al}_{2} \mathrm{O}_{3}$ 粒子の

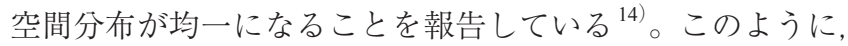
粒状の第 2 相粒子を持つ複相材料への巨大ひずみ加工は, 加 工方法にかかわらず第 2 相粒子の空間分布を均一化すること が知られている。一方, Watanabeらは, 長軸長さが $200 \mu \mathrm{m}$ 以上である板状 $\mathrm{Al}_{3} \mathrm{Ti}$ 粒子が $\alpha-\mathrm{Al}$ 母相中に分散した $\mathrm{Al}_{-}-\mathrm{Al}_{3} \mathrm{Ti}$ 複相材料にRoute A あるいはRoute $\mathrm{B}_{\mathrm{c}}$ の加工経路にて 4 パス の繰返し押出加工 (Equal-Channel Angular Pressing: ECAP) を施し, ECAPに伴う板状 $\mathrm{Al}_{3}$ Ti 粒子分布の変化について調 べた ${ }^{7)}$ 。その際, 複相材料中の板状 $\mathrm{Al}_{3} \mathrm{Ti}$ 粒子は ECAPによっ て微細化し, かつ板状 $\mathrm{Al}_{3} \mathrm{Ti}$ 粒子の空間分布が加工経路に依 存することを見いだしている。さらに, Satoらは, ECAPを 施した $\mathrm{Al}-\mathrm{Al}_{3} \mathrm{Ti}$ 複相材料の板状 $\mathrm{Al}_{3} \mathrm{Ti}$ 粒子分布をシリアルセ

*名古屋工業大学（广466-8555 愛知県名古屋市昭和区御器所町） Department of Physical Science and Engineering, Graduate School of Engineering, Nagoya Institute of Technology (Gokiso-cho, Showa-ku, Nagoya-shi, Aichi 466-8555) E-mail: sato.hisashi@nitech.ac.jp

**名古屋工業大学大学院生 (名古屋市)〔現在：トヨ夕自動車株式会社〕 Graduate Student, Department of Engineering Physics, Electronics and Mechanics, Graduate School of Engineering, Nagoya Institute of Technology (Nagoya-shi, Aichi)〔Present: Toyota Motor Corporation〕 
クショニングにて 3 次元可視化することで，その複相材料中 の板状 $\mathrm{Al}_{3} \mathrm{Ti}$ 粒子の空間分布が母相の塑性流動に依存するこ とを報告している ${ }^{10)}$ 。

このように，巨大ひずみ加工を施した板状粒子を持つ複 相材料の粒子寸法やその空間分布は，粒状粒子を有する複 相材料と異なり，その加工方法に依存した母相の塑性流動 によって決定することがわかっている7),10)。一方，このよ うな板状粒子の寸法や空間分布は加工中の温度にも依存する であろう。これは, 母相に動的回復や動的再結晶が生じるよ うな高温環境下で加工を施した場合，母相の硬さが低下し， 剪断変形に伴う板状粒子の破壊が生じにくくなるためであ $3^{20) \sim 23)}$ 。しかし，巨大ひずみ加工における加工温度が板状 粒子を持つ複相材料の粒子分布に及ぼす影響については報告 されていない。

本研究では, $\mathrm{Al}-\mathrm{Al}_{3} \mathrm{Ti}$ 複相材料に対して室温（Room

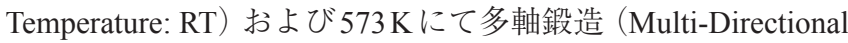
Forging: MDF）を施し，鍛造温度が板状 $\mathrm{Al}_{3} \mathrm{Ti}$ 粒子の破壊お よび分散挙動に及ぼす影響について調べた。また，本研究 では，破壊した板状 $\mathrm{Al}_{3} \mathrm{Ti}$ 粒子の集中度を森下指数 $I_{\delta}$ にて定 量的に評価 ${ }^{24)}$ 26)，MDFに伴う板状 $\mathrm{Al}_{3} \mathrm{Ti}$ 粒子の空間分布 の変化も調査した。その結果, 巨大ひずみ加工を施した $\mathrm{Al}$ $\mathrm{Al}_{3} \mathrm{Ti}$ 複相材料の $\mathrm{Al}_{3} \mathrm{Ti}$ 粒子分布は母相の塑性流動および鍛造 温度に依存することを本研究の新たな知見として明らかにし ている。

さらに, 本研究で用いる $\mathrm{Al}_{-}-\mathrm{Al}_{3} \mathrm{Ti}$ 複相材料は, $\mathrm{Al}_{3} \mathrm{Ti}$ 粒子 がアルミニウム凝固の異質核として作用することから，ア ルミニウム鋳造材の結晶粒微細化剤として知られている ${ }^{27)} 。$ 詳細は後で述べるが, $\mathrm{Al}-\mathrm{Al}_{3} \mathrm{Ti}$ 複相材料への MDFによって, $\mathrm{Al}_{3} \mathrm{Ti}$ 粒子が微細化し，かつ形状も粒状に変化する。そのた め, $\mathrm{Al}-\mathrm{Al}_{3} \mathrm{Ti}$ 複相材料への MDF は，アルミニウム凝固の異 質核となる $\mathrm{Al}_{3} \mathrm{Ti}$ 粒子の数密度を増加させると同時にアルミ ニウムとの界面マッチングを改善させることにつながるた め, アルミニウム鋳造材に対する $\mathrm{Al}-\mathrm{Al}_{3} \mathrm{Ti}$ 複相材料の結晶粒 微細化能を向上させることが期待できる。そこで，本研究で は, $\mathrm{Al}-\mathrm{Al}_{3} \mathrm{Ti}$ 複相材料への MDFの工業的利用として, アル ミニウム鋳造材の結晶粒微細化剂への適用可能性についても 検討した。

\section{2. 実 験方法}

本研究では，供試材として Al-5 mass\%Ti合金インゴット を用いた。このインゴットを $\mathrm{Ar}$ 雲囲気中で溶解温度 $1073 \mathrm{~K}$ にて鋳造し，直径 $48 \mathrm{~mm}$ および高さ $80 \mathrm{~mm}$ の円柱状鋳造材 を得た。その後, この鋳造材から, 機械加工および研磨に て $20.0 \mathrm{~mm} \times 28.0 \mathrm{~mm} \times 39.0 \mathrm{~mm}$ (寸法比：1.00:1.40:1.95）の形 状を持つ MDF 試料を作製した。なお，本研究では，組織観 察方向を明確に示すために Fig. 1 に示す試料座標系を設定し た。

作製した MDF 試料に対し， RTおよび $573 \mathrm{~K} に て \mathrm{MDF}$ 行った。MDF拈ける1パス目，2パス目および3パス目の 鍛造方向は，それぞれFig. 1 に示すZ方向，X方向およびY 方向である。また，MDFに拈けるひずみ速度は $6.7 \times 10^{-3} 1 / \mathrm{s}$ とし，1パスあたりに導入する対数ひずみ量を 0.67 とした。 なお，本研究におけるMDFは，鍛造治具と試料の間にh-BN 潤滑材を塗布し，かつ試料形状を拘束するための金型を用い

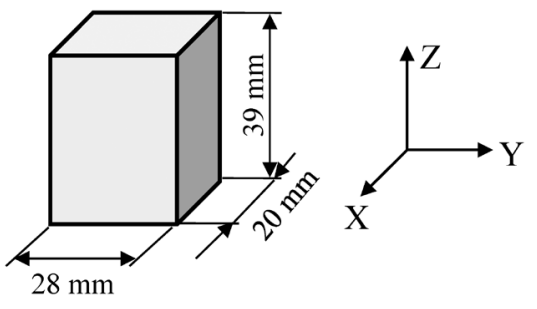

Fig. 1 Schematic illustration of the MDF specimen and specimen coordinate system.

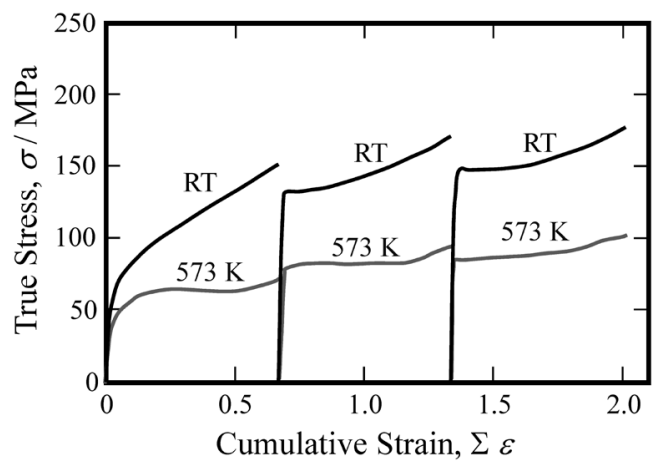

Fig. 2 True stress-cumulative strain curves of $\mathrm{Al}-\mathrm{Al}_{3} \mathrm{Ti}$ multi-phase material subjected to MDF at RT or $573 \mathrm{~K}$.

ずに行った。

MDFを施した試料の最終鍛造方向と垂直になる面に対し， 走査型電子顕微鏡（Scanning Electron Microscope: SEM）およ び電子線後方散乱回折法 (Electron Backscattering Diffraction: EBSD）にて組織観察を行った。このとき, 本研究では, 試 料中心部の $\mathrm{Al}_{3} \mathrm{Ti}$ 粒子分布に着目して微細組織を観察してい る。さらに, 本研究では MDFを施した試料における $\alpha-\mathrm{Al}$ 母 相のビッカース硬さを測定した。なお, 測定条件は, 荷重を $0.098 \mathrm{~N}$ および荷重印加時間を $15 \mathrm{~s}$ とした。

\section{3. 実験結果および考察}

\section{1 MDF に伴う応力-累積ひずみ曲線および $a-A I$ 母相の 硬さ変化}

Fig. 2 は，RTおよび573Kにて MDFを行った試料の典型 的な応力一累積ひずみ曲線である。RTでの MDFでは, すべ ての鍛造パスにおいて加工硬化が生じていた。一方， $573 \mathrm{~K}$ におけるMDFでは，RTでの MDFに比べて流動応力が小さ

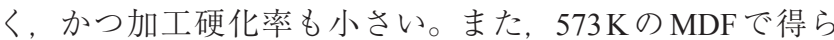
れた応力ー累積ひずみ曲線は，すべての鍛造パスにおいて 定常状態変形を示していた。この鍛造温度である $573 \mathrm{~K} は$, $\alpha-\mathrm{Al}$ 母相に動的回復や動的再結晶が生じることが推測される $0.5 T_{\mathrm{m}}\left(T_{\mathrm{m}}\right.$ : 融点, $\left.T_{\mathrm{m}}=938 \mathrm{~K}^{28)}\right)$ である $469 \mathrm{~K}$ を超えている。 さらに，中尾らは，MDFにおける応力一累積ひずみ曲線の形 状に定常状態変形がみられた場合，変形中に動的回復が生じ ていることを報告している ${ }^{22)}$ 。それゆえ，573KでMDFを施 した試料では鍛造中に $\alpha-\mathrm{A} 1$ 母相で動的回復や動的再結晶が 生じていると考えられる。

そこで，本研究では，すべての試料に対して $\alpha-\mathrm{Al}$ 母相の ビッカース硬さを調べた。Fig. 3 は, 累積ひずみの変化に 伴う $\alpha-\mathrm{A} 1$ 母相のビッカース硬さ変化を示している。 $\mathrm{RT} に て$ $\mathrm{MDF}$ を施した試料では, 累積ひずみの増加に伴って $\alpha$-Al母 


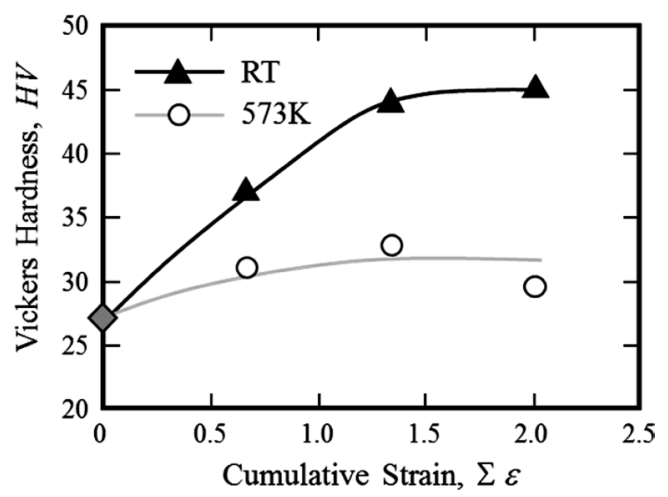

Fig. 3 Vickers hardness of $\alpha-\mathrm{Al}$ matrix in the $\mathrm{Al}-\mathrm{Al}_{3} \mathrm{Ti}$ multi-phase materials subjected to MDF at RT or $573 \mathrm{~K}$ as a function of cumulative strain.

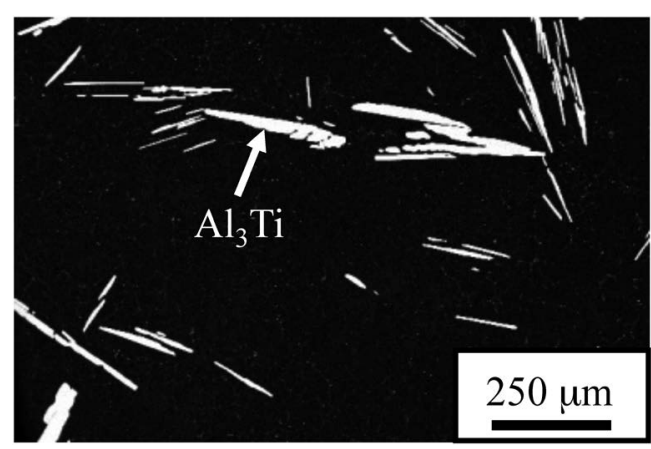

Fig. 4 Backscatter electron compositional (BEC) image showing the microstructure of the $\mathrm{Al}-\mathrm{Al}_{3} \mathrm{Ti}$ multi-phase material before MDF.

相の硬さが増加した。一方，573KでMDFを行った試料に おける $\alpha-\mathrm{Al}$ 母相の硬さは，累積ひずみの増加にかかわらず， 大きな変化が生じていない。また, 次節にて結果を示すが, $573 \mathrm{~K} に て \mathrm{MDF}$ を施した試料の $\alpha-\mathrm{Al}$ 母相には，動的再結晶に て生成した微細粒が観察された。それゆえ，573 KでのMDF では，鍛造中に動的再結晶が $\alpha-\mathrm{Al}$ 母相にて生じているため, RTでの MDFに比べて流動応力や加工硬化が小さいといえ る。

\section{2 MDFを施した複相材料の微細組織に及ぼす鍛造温度 の影響}

$\mathrm{MDF}$ 前の $\mathrm{Al}-\mathrm{Al}_{3} \mathrm{Ti}$ 複相材料の微細組織を Fig. 4 に示す。 Fig. 4 において白色の細長い粒子は $\mathrm{Al}_{3} \mathrm{Ti}$ 粒子である。遠心 鋳造による粒子配向 ${ }^{29)}$ やシリアルセクショニングによる 3 次元可視化 ${ }^{11)}$ により, この細長い粒子の形状が板状である ことがわかっている。このように, $\mathrm{MDF}$ 前の $\mathrm{Al}-\mathrm{Al}_{3} \mathrm{Ti}$ 複相 材料には，長軸長さが $200 \mu \mathrm{m}$ 以上の板状 $\mathrm{Al}_{3} \mathrm{Ti}$ 粒子が分散し ていた。また，これらの $\mathrm{Al}_{3} \mathrm{Ti}$ 粒子の長手方向はランダムに 向いている。Fig. 5(a) および（b）は，それぞれRTおよび $573 \mathrm{~K} に て \mathrm{MDF}$ を施した試料の微細組織を示している。板状 $\mathrm{Al}_{3} \mathrm{Ti}$ 粒子は, 鍛造温度にかかわらずMDFに伴って破壊し, 微細化していた。また，破壊した板状 $\mathrm{Al}_{3} \mathrm{Ti}$ 粒子は，粒子長 手方向が特定の方向に揃うなど配向分布を形成していない。 過去の研究において, $\mathrm{Al}-\mathrm{Al}_{3} \mathrm{Ti}$ 複相材料にRoute Aの加工経 路で $\mathrm{ECAP}^{7)}$ あるいは圧下率 $53 \%$ の圧延加工 ${ }^{12)}$ を施すと, 板状 $\mathrm{Al}_{3} \mathrm{Ti}$ 粒子の破壊と同時に粒子長手方向が加工方向に配 向することが報告されている。しかし，本研究のMDFの場
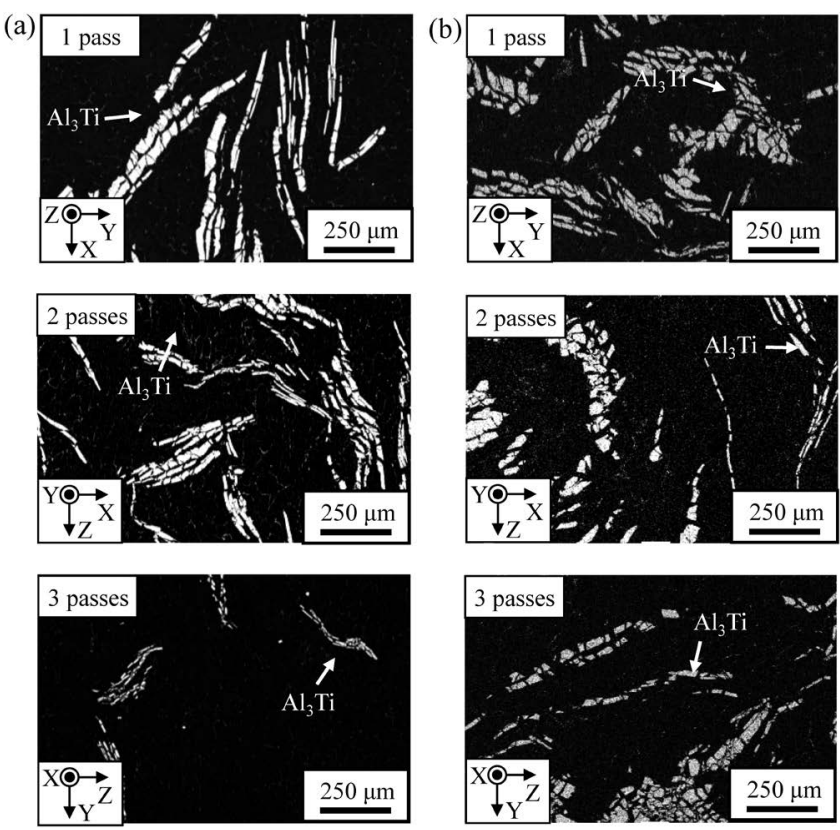

Fig. 5 BEC images showing the microstructures of the Al$\mathrm{Al}_{3} \mathrm{Ti}$ multi-phase materials subjected to MDF at (a) RT or (b) $573 \mathrm{~K}$. The upper, middle, and lower images in (a) and (b) depict specimens subjected to 1,2 , and 3 passes of $\mathrm{MDF}$, respectively.
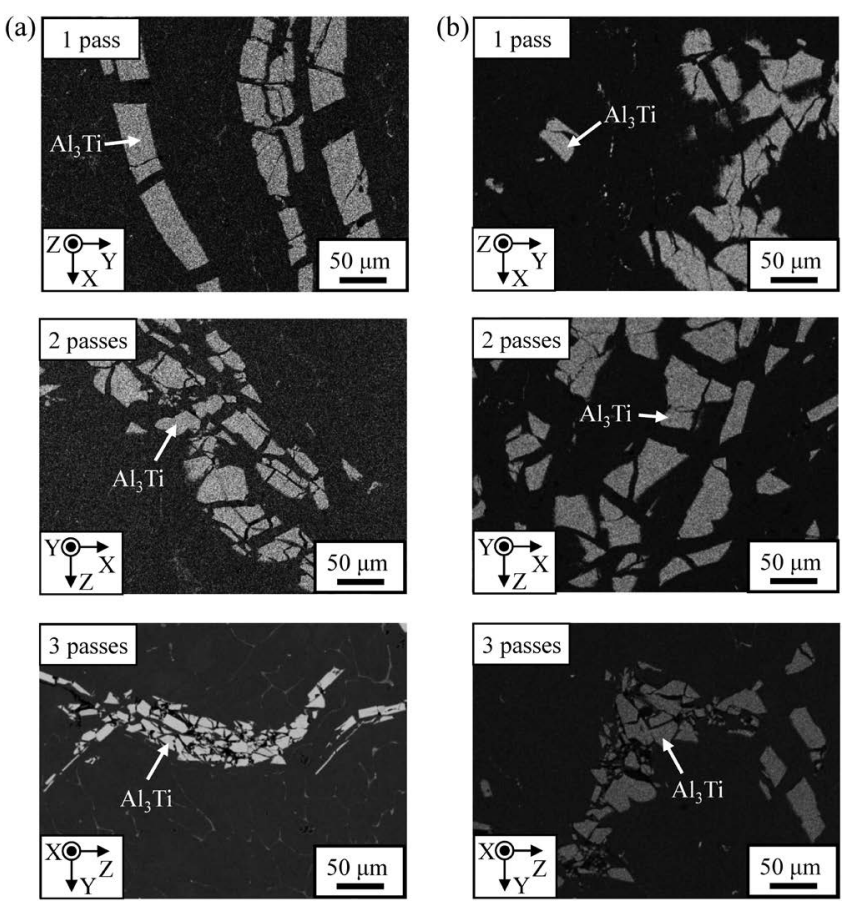

Fig. 6 High-magnification BEC images showing the microstructures of the $\mathrm{Al}-\mathrm{Al}_{3} \mathrm{Ti}$ multi-phase materials subjected to MDF at (a) RT or (b) $573 \mathrm{~K}$. The upper, middle, and lower images in (a) and (b) depict specimens subjected to 1,2 , and 3 passes of MDF, respectively.

合は， 1 パスあたりの鍛造で導入される対数ひずみ量が 0.67 と小さいことや 3 方向から鍛造を加えていることから, 板状 $\mathrm{Al}_{3} \mathrm{Ti}$ 粒子に配向分布が生じにくいといえる。

さらに, これらの MDF後の試料に対する高倍率組織写真 を Fig. 6 に示す。 $\mathrm{Al}_{3} \mathrm{Ti}$ 粒子の形状は, 鍛造温度にかかわらず, 
(a)
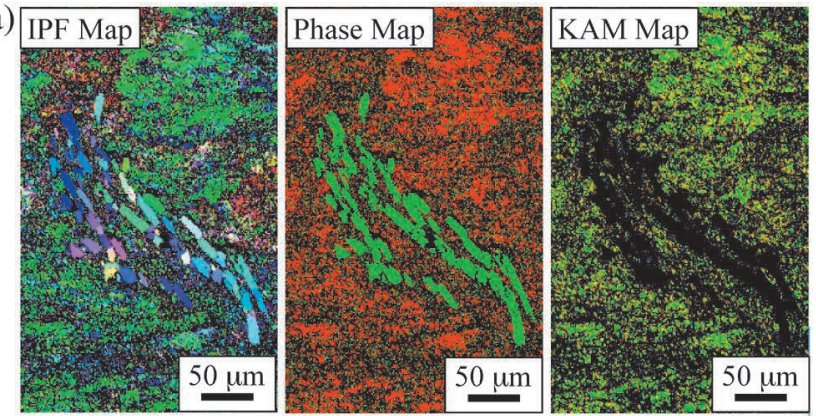

(b)
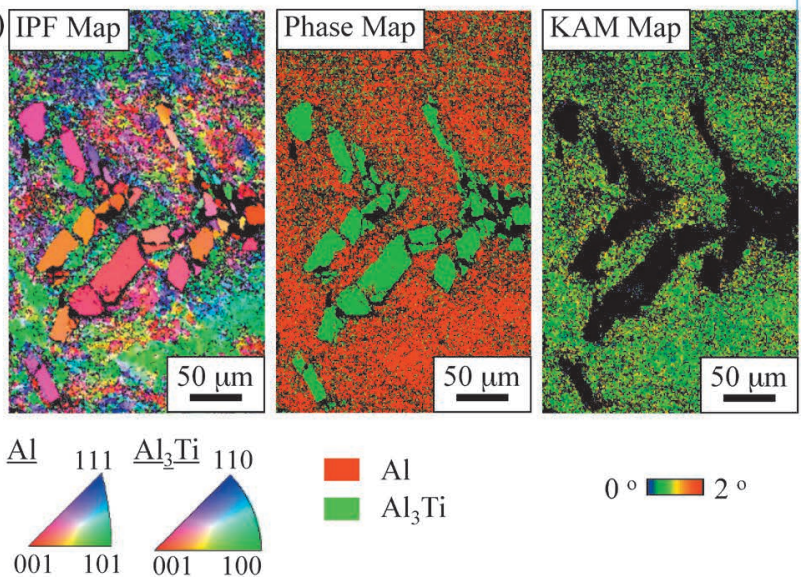

$\mathrm{Al}_{3} \mathrm{Ti}$

$0^{\circ} \square 2$

Fig. 7 IPF, phase, and KAM maps of the $\mathrm{Al}_{-}-\mathrm{Al}_{3} \mathrm{Ti}$ multiphase materials subjected to 3 passes of MDF at (a) RT or (b) $573 \mathrm{~K}$

MDFに伴って板状から粒状に変化していた。また， $\mathrm{Al}_{3} \mathrm{Ti}$ 粒 子は, 鍛造パスの増加に伴ってより微細化している。 RT お

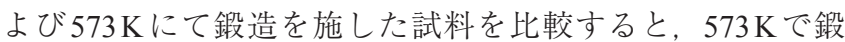
造した試料中の $\mathrm{Al}_{3} \mathrm{Ti}$ 粒子の方が大きい。次に示す Fig. 7 で

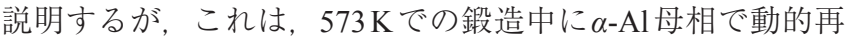
結晶が発生し, $\mathrm{Al}_{3} \mathrm{Ti}$ 粒子周りの $\alpha-\mathrm{Al}$ 母相における転位密度 が低下することに起因する。

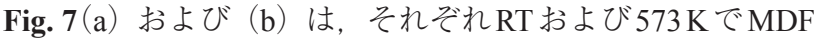
を3パス施した $\mathrm{Al}-\mathrm{Al}_{3} \mathrm{Ti}$ 複相材料の逆極点図マップ (Inverse Pole Figure: IPF)，Phase マップおよび $\alpha$-Al 母相中の Kernel Average Misorientation（KAM）マップである。IPFマップか らわかるように，573K で鍛造を施した試料の $\alpha-\mathrm{Al}$ 母相に は微細で等軸状の再結晶粒が形成していた。また，この試 料の $\alpha-\mathrm{Al}$ 母相における KAM は, RTでの鍛造材に比べて低 い。KAMは幾何学的に必要な転位 (Geometrically Necessary Dislocation: GND）の密度に対応することが知られている ${ }^{30)}$ そのため， $573 \mathrm{~K} て ゙ \mathrm{MDF}$ を施した試料の $\alpha-\mathrm{Al}$ 母相では， RT で鍛造をした試料に比べて GND密度が低いことから，鍛造 中に動的再結晶が生じていることがいえる。これらのEBSD

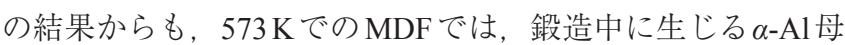
相での動的再結晶にて $\mathrm{Al}_{3} \mathrm{Ti}$ 粒子周りの $\alpha-\mathrm{Al}$ 母相における転 位密度が低下し， $\mathrm{Al}_{3} \mathrm{Ti}$ 粒子の破壊が生じにくくなることが わかる。

\section{3. $3 \mathrm{MDF}$ を施した複相材料の $\mathrm{Al}_{3} \mathrm{Ti}$ 粒子寸法に及ぼす鍛造 温度の影響}

$\mathrm{RT}$ および $573 \mathrm{~K} に て \mathrm{MDF}$ を施した $\mathrm{Al}-\mathrm{Al}_{3} \mathrm{Ti}$ 複相材料にお ける $\mathrm{Al}_{3} \mathrm{Ti}$ 粒子寸法の分布を示すヒストグラムを Fig. 8 に示

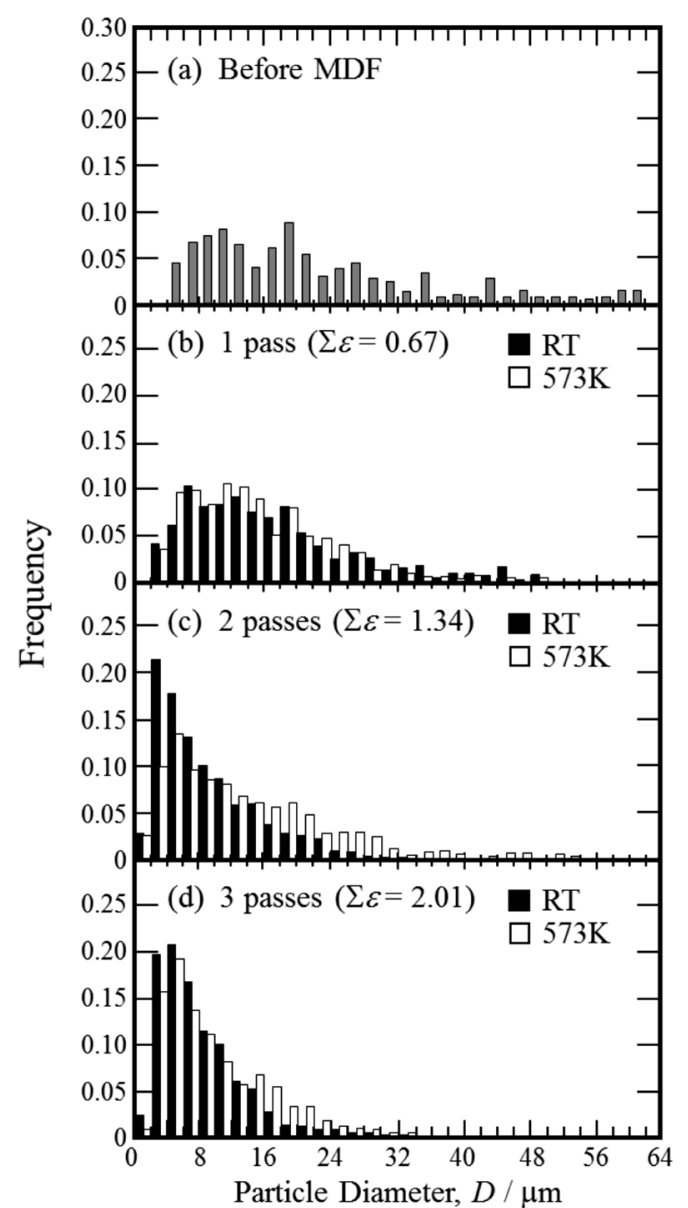

Fig. 8 Particle diameter distributions of $\mathrm{Al}_{3} \mathrm{Ti}$ particles in the specimens (a) before MDF and after (b) 1, (c) 2, and (d) 3 passes of MDF at RT or $573 \mathrm{~K}$.

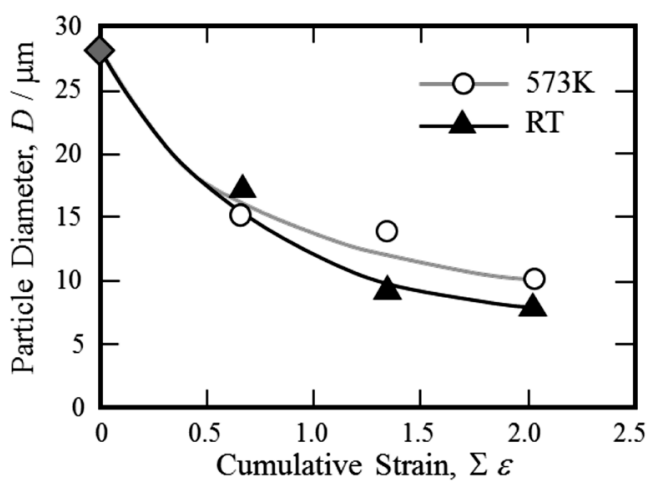

Fig. 9 Variation of the $\mathrm{Al}_{3} \mathrm{Ti}$ particle diameters in the $\mathrm{Al}-$ $\mathrm{Al}_{3} \mathrm{Ti}$ multi-phase materials subjected to MDF at RT or $573 \mathrm{~K}$ as a function of cumulative strain.

す。なお，この $\mathrm{Al}_{3} \mathrm{Ti}$ 粒子寸法は，断面形状を円と仮定して 粒子面積から算出した直径である。さらに，これらのヒス トグラムから算出した $\mathrm{Al}_{3} \mathrm{Ti}$ 粒子の平均粒子直径と累積ひず みの関係を Fig.9に示す。Fig. 8 およびFig. 9 から, $\mathrm{Al}_{3} \mathrm{Ti}$ 粒子 は，鍛造温度にかかわらず累積ひずみが大きくなるにつれて 微細化していた。また, Fig. 8 から $\mathrm{Al}_{3} \mathrm{Ti}$ 粒子分布の幅は, 累 積ひずみが増加するにつれて狭くなっている。よって，板状 粒子を持つ複相材料への巨大ひずみ加工は, 板状粒子を微細 化すると同時に，粒子寸法を均一にする効果を持つことがい 
える。

さらに，RT および $573 \mathrm{~K}$ で MDFを施した試料の $\mathrm{Al}_{3} \mathrm{Ti}$ 粒子 直径を比較すると， $573 \mathrm{~K} に て$ 鍛造した試料の $\mathrm{Al}_{3} \mathrm{Ti}$ 粒子は, RTで鍛造した試料に比べて大きく，かつ粒子分布の幅も広 い。これは，鍛造温度が高くなるほど MDFによる $\mathrm{Al}_{3} \mathrm{Ti}$ 粒子 の破壊が生じにくくなることを意味する。

過去の研究において, 柔らかい母相中に硬質粒子が分散し た複合材料の場合，母相に生じる塑性変形によって，硬質粒 子に割れあるいは母相と粒子界面に剥離が生じることが報告 されている ${ }^{31)}$ 。また，母相と硬質粒子との結合性が良好で ある場合は，母相の塑性変形で硬質粒子に作用する応力状態 が3 軸応力状態になるため, 硬質粒子に割れが発生しやすい。 本研究で用いた $\mathrm{Al}_{-}-\mathrm{Al}_{3} \mathrm{Ti}$ 複相材料中の $\alpha-\mathrm{Al}$ 母相と $\mathrm{Al}_{3} \mathrm{Ti}$ 粒子 は, 両者の間で結晶の整合性が比較的優れているため ${ }^{32)}$, 良好な結合性を持つと考えられる。そのため, 本研究で用い た $\mathrm{Al}-\mathrm{Al}_{3} \mathrm{Ti}$ 複相材料は，母相の塑性変形によって $\mathrm{Al}_{3} \mathrm{Ti}$ 粒子 の破壊が生じるといえる。ここで, $\mathrm{Al}-\mathrm{Al}_{3} \mathrm{Ti}$ 複相材料への鍛 造で板状 $\mathrm{Al}_{3} \mathrm{Ti}$ 粒子を破壊するために必要な条件を考えると, 板状 $\mathrm{Al}_{3} \mathrm{Ti}$ 粒子の破壊に必要な条件は「母相の塑性流動に起 因した $\mathrm{Al}_{3} \mathrm{Ti}$ 粒子の剪断変形」および「 $\mathrm{Al}_{3} \mathrm{Ti}$ 粒子を破壊する ために必要な母相の硬さ」であると考えられる。鍛造に伴う $\alpha-\mathrm{Al}$ 母相の塑性流動は, 鍛造温度が高いほど活発に生じる。

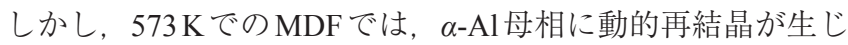
ており， $\alpha-\mathrm{Al}$ 母相の剪断変形によって $\mathrm{Al}_{3} \mathrm{Ti}$ 粒子周りの $\alpha-\mathrm{Al}$ 母相に堆積した転位が回復して転位密度が低下していると考

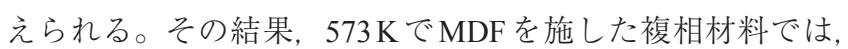
$\mathrm{RT}$ での MDFに比べて $\mathrm{Al}_{3} \mathrm{Ti}$ 粒子の破壊が生じにくく, $\mathrm{Al}_{3} \mathrm{Ti}$ 粒子の寸法が大きくなるといえる。

\section{3. $4 \mathrm{MDF}$ を施した複相材料の $\mathrm{Al}_{3} \mathrm{Ti}$ 粒子の空間分布に及ぼ す鍛造温度の影響}

過去の研究において, 巨大ひずみ加工を施した $\mathrm{Al}^{-} \mathrm{Al}_{3} \mathrm{Ti}$ 複相材料における $\mathrm{Al}_{3} \mathrm{Ti}$ 粒子の空間分布は, 加工にて生じる $\alpha-\mathrm{Al}$ 母相の塑性流動に依存することが報告されている ${ }^{10)}$ 。 そこで, 本研究では, MDFによって破壊した $\mathrm{Al}_{3} \mathrm{Ti}$ 粒子の空 間分布を粒子の集中度の観点から評価した。

森下は, 数理生態学において, 観察領域に存在する点（粒 子）の集中度を定量的に示す手法として $I_{\delta}$ を提案してい る $^{24)}$ 。この手法は, 観察領域を等面積の小さな区画に分け て評価する区画法の一つであり，曲げ疲労が生じた炭素鋼に おける亀裂の空間分布 ${ }^{25)}$ や粒子分散強化複合材料における 粒子の空間分布 ${ }^{26)}$ の評価などに用いられている。観察領域 を区画数 $q$ だけ分割した場合， $I_{\delta}$ は次式にて得ることができ る。

$$
\begin{gathered}
I_{\delta}=q \cdot \delta \\
\delta=\frac{\sum_{i=1}^{q} n_{i}\left(n_{i}-1\right)}{N(N-1)} \\
N=\sum_{i=1}^{q} n_{i}
\end{gathered}
$$

ここで, $n_{i}$ は $i$ 番目の区画における粒子数および $N$ は全粒子 数である。一般的に, この $I_{\delta} に よ る$ 粒子の空間分布は, $q$ の 変化に伴う $I_{\delta}$ の変化パターンに基づいて評価されている。 Fig. 10 は， $I_{\delta}$ と $q$ の関係を示す典型的な曲線，およびそれに 対応した粒子分布の模式図を示す。粒子の空間分布がポアソ

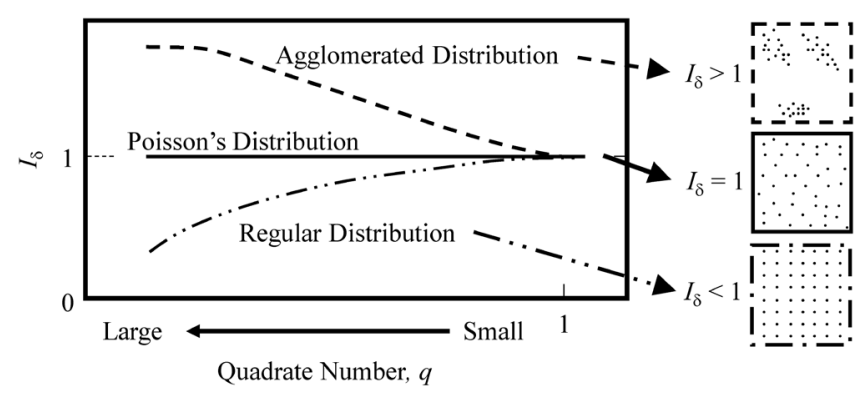

Fig. 10 Schematic illustration showing typical curves of $I_{\delta}$ as a function of $q$. The illustrations on the right depict the particle distributions for each $I_{\delta}-q$ curve.

(a)

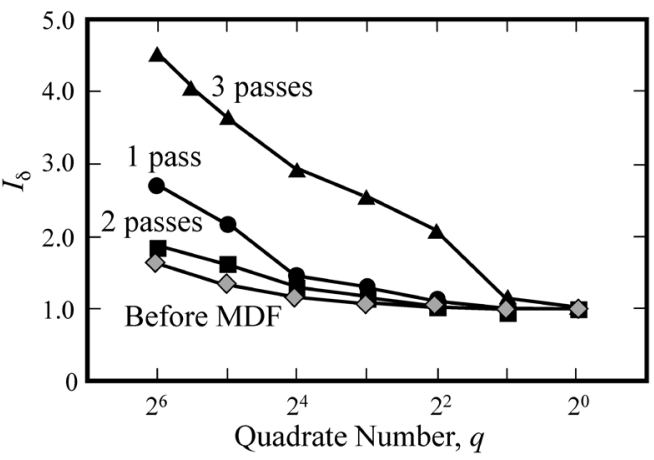

(b)

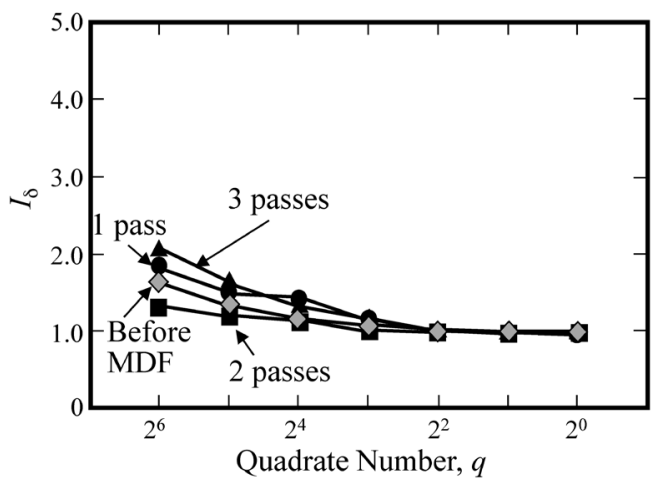

Fig. $11 I_{\delta}-q$ curves of $\mathrm{Al}-\mathrm{Al}_{3} \mathrm{Ti}$ multi-phase materials subjected to MDF at (a) RT or (b) $573 \mathrm{~K}$.

ン分布（ランダム分布）である場合は, $q$ が増加しても $I_{\delta}=1$ となる。一方，粒子が同程度の粒子間距離を持つ規則分布で あるとき， $I_{\delta}$ は $q$ の増加にかかわらず1よりも小さい。さら に，粒子が集団（凝集）を形成している集中分布となってい るときの $I_{\delta}$ は, 1 より大きい值となる。よって, MDFを施し た試料に対し， $I_{\delta}$ と $q$ の関係を示すパターンを調査すること で, MDFに伴う $\mathrm{Al}_{3} \mathrm{Ti}$ 粒子の空間分布の変化を評価すること ができる。

RTおよび $573 \mathrm{~K} に て \mathrm{MDF}$ を施した $\mathrm{Al}-\mathrm{Al}_{3} \mathrm{Ti}$ 複相材料にお ける $I_{\delta}$ と q関係を，それぞれFig. 11 (a) および (b) に示す。 なお，本研究では， $\mathrm{Al}_{3} \mathrm{Ti}$ 粒子の重心位置を粒子の位置とし， 各区画内の粒子数を測定することで $I_{\delta}$ を算出した。また, Fig. 11 の結果に基づいた板状 $\mathrm{Al}_{3} \mathrm{Ti}$ 粒子の破壊過程を Fig. 12 の模式図に示す。Fig. 11 より, MDFを1パスだけ施すと， I は鍛造温度にかかわらず増加した。1パスの鍛造で $\mathrm{Al}_{3} \mathrm{Ti}$ 粒 子が破壊し, $\mathrm{Al}_{3} \mathrm{Ti}$ 粒子の集団が形成したためである（Fig. $12(\mathrm{a}))$ 。また, MDFを2パス施すと $\mathrm{I}_{\delta}$ は低下した。これは, 
(a)
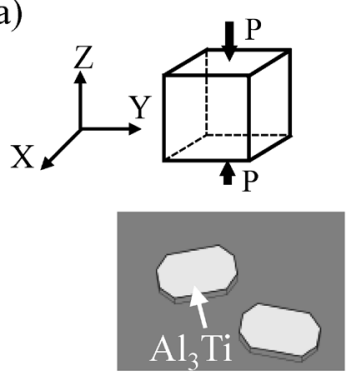

(c)
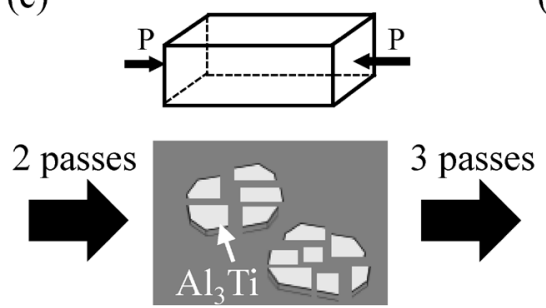

(b)

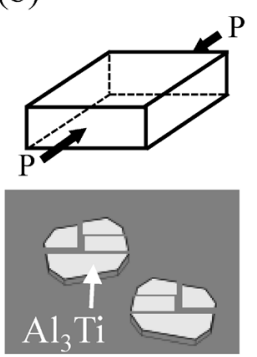

(d)
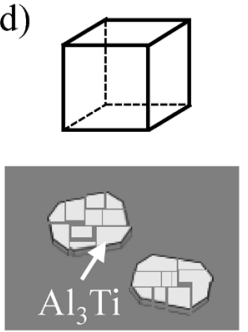

Fig. 12 Schematic illustrations showing the fragmentation process of $\mathrm{Al}_{3} \mathrm{Ti}$ particles in the $\mathrm{Al}-\mathrm{Al}_{3} \mathrm{Ti}$ multi-phase material during MDF: (a) before MDF, (b) after 1 pass, (c) after 2 passes, (d) after 3 passes.

2パス目の鍛造を1パス目と異なる方向から施しているため, Fig. 12(b) に示すように破壊した $\mathrm{Al}_{3} \mathrm{Ti}$ 粒子がより広い領域 に分散したことに起因する。さらに, MDFを3パス施した場 合， $I_{\delta}$ は最も大きくなった。つまり，破壊した $\mathrm{Al}_{3} \mathrm{Ti}$ 粒子は, 3パス目のMDFにて最も顕著に集団を形成することがいえ る。MDFでは，3パス目で試料形状が元に戻るような塑性流 動が母相に生じる。そのため, MDFにて破壊した $\mathrm{Al}_{3} \mathrm{Ti}$ 粒子 は, 3 パス目で MDF 前の位置に戻り， $\mathrm{Al}_{3} \mathrm{Ti}$ 粒子の形状を示 唆するように集団を形成するのであろう（Fig. 12(c)）。この $\mathrm{MDF}$ に伴う $\mathrm{Al}_{3} \mathrm{Ti}$ 粒子の空間分布の変化は, 鍛造温度にかか わらず生じていた。よって, MDFに伴う $\mathrm{Al}-\mathrm{Al}_{3} \mathrm{Ti}$ 複相材料 の空間分布は母相の塑性流動に依存していることが明らかで ある。

Fig. 11（a）および（b）を比較すると，RTにてMDFを施し た複相材料は, $573 \mathrm{~K} に て$ 鍛造した複相材料に比へてて $\mathrm{Al}_{3} \mathrm{Ti}$ 粒 子の空間分布の変化が大きい。そこで，鍛造温度の変化に 伴う $\mathrm{Al}_{3} \mathrm{Ti}$ 粒子空間分布の違いに関する理由について検討す る。MDFによって板状 $\mathrm{Al}_{3} \mathrm{Ti}$ 粒子が微細化した場合, 微細化 された個々の $\mathrm{Al}_{3} \mathrm{Ti}$ 粒子は, 孤立した $\mathrm{Al}_{3} \mathrm{Ti}$ 粒子として $\alpha-\mathrm{Al}$ 母 相中に分散する。また，これらの微細化された $\mathrm{Al}_{3} \mathrm{Ti}$ 粒子は, $\alpha-\mathrm{A} 1$ 母相の塑性流動に従って個々に移動することができる。 そのため, 一つの板状 $\mathrm{Al}_{3} \mathrm{Ti}$ 粒子が MDFによってより微細に なるほど，微細化された $\mathrm{Al}_{3} \mathrm{Ti}$ 粒子は $\alpha-\mathrm{Al}$ 母相の塑性流動に 従ってより広い領域に分散すると考えられる。前で述べたよ うに, $\mathrm{RT}$ で MDFを施した $\mathrm{Al}-\mathrm{Al}_{3} \mathrm{Ti}$ 複相材料中の $\mathrm{Al}_{3} \mathrm{Ti}_{\text {粒子 }}$ の寸法は, $573 \mathrm{~K}$ で鍛造した試料中の $\mathrm{Al}_{3} \mathrm{Ti}$ 粒子に比べて小さ い。そのため, RTでMDFを施した方が，微細化された $\mathrm{Al}_{3} \mathrm{Ti}$ 粒子をより広い領域に分散できると考えられる。その結果, $\mathrm{MDF}$ に伴う $\mathrm{Al}_{3} \mathrm{Ti}$ 粒子の空間分布の変化は, $\mathrm{RT}$ での鍛造の 方が大きくなるであろう。よって，巨大ひずみ加工を施した 板状粒子を持つ複相材料中に扔ける粒子空間分布は, 加工温 度に依存することがいえる。

\section{3. $5 \mathrm{MDF}$ を施した $\mathrm{Al}-\mathrm{Al}_{3} \mathrm{Ti}$ 複相材料の工業的応用}

本研究では, 鍛造温度にかかわらずMDFに伴って $\mathrm{Al}$ $\mathrm{Al}_{3} \mathrm{Ti}$ 複相材料の $\mathrm{Al}_{3} \mathrm{Ti}$ 粒子が板状から粒状に変化することを 見いだした。ところで, $\mathrm{Al}^{-} \mathrm{Al}_{3} \mathrm{Ti}$ 複相材料はアルミニウム 鋳造に扮ける結晶粒微細化剂 27)でもあり, 同微細化剂中の $\mathrm{Al}_{3} \mathrm{Ti}$ 粒子が凝固の異質核として働くものと考えている ${ }^{32}$ 。 ここで, $\mathrm{Al}_{3} \mathrm{Ti}$ は結晶の対称性が悪い $\mathrm{D}_{22}$ 構造であり,アル ミニウムと比較した場合, $\mathrm{Al}_{3} \mathrm{Ti}$ は $a$ 軸方向では $5 \%$ 縮んでい るのに対し， $c$ 軸方向には $6 \%$ 伸びた結晶構造となっている。 したがって, $\mathrm{Al}_{3} \mathrm{Ti}$ と $\mathrm{Al}$ との界面マッチングは結晶面ごとに 異なるため, $\mathrm{Al}_{3} \mathrm{Ti}$ 異質核粒子の結晶粒微細化能は結晶面ご とに異なり ${ }^{12)}$, 33)，形状により結晶粒微細化能が変化すると 考えられる ${ }^{33), 34)}$ 。本実験でも示したように, 結晶粒微細化 剂中の $\mathrm{Al}_{3} \mathrm{Ti}$ 粒子は板状であり，その板面は $(001)_{\mathrm{Al} 3 \mathrm{Ti}}$ である が35)，この面はアルミニウムとの格子マッチングのよくな い面である。したがって, MDFによって $\mathrm{Al}_{3} \mathrm{Ti}$ 板状粒子を破 壊することは, 単に異質核の数密度を増加させるのみなら ず，より格子マッチングのよい面を創出することになる。こ のように, MDFを結晶粒微細化凨に施せば, 結晶粒微細化 能向上につながると考えられる。

\section{4. 結言}

板状 $\mathrm{Al}_{3} \mathrm{Ti}$ 粒子を有する $\mathrm{Al}-\mathrm{Al}_{3} \mathrm{Ti}$ 複相材料に対して室

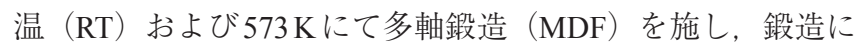
伴う $\mathrm{Al}_{3} \mathrm{Ti}$ 粒子の寸法拉よび空間分布の変化について調べた。 主な結果は以下の通りである。

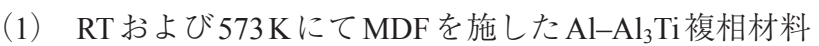
の粒子寸法は累積ひずみの増加に伴って小さくなる。また， $573 \mathrm{~K}$ で MDFを施した $\mathrm{Al}_{-} \mathrm{Al}_{3} \mathrm{Ti}$ 複相材料の $\mathrm{Al}_{3} \mathrm{Ti}$ 粒子直径は, RTでMDFを施した複相材料に比べて大きかった。この複相 材料中の $\mathrm{Al}_{3} \mathrm{Ti}$ 粒子は $\alpha-\mathrm{Al}$ 母相の剪断変形によって破壊する。 しかし， $573 \mathrm{~K} て ゙ の \mathrm{MDF}$ では, MDF中に生じる $\alpha-\mathrm{Al}$ 母相で

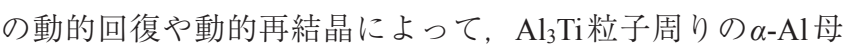
相に堆積した転位が回復し, 転位密度が低下する。その結果, $573 \mathrm{~K}$ での MDFでは, RTでの MDFに比べて $\mathrm{Al}_{3} \mathrm{Ti}_{\text {粒子の破 }}$ 壊が生じにくくなる。

(2) $\mathrm{MDF}$ に伴う $\mathrm{Al}_{3} \mathrm{Ti}$ 粒子の空間分布変化を森下指数 $I_{\delta}$ にて評価した結果， $\mathrm{Al}_{3} \mathrm{Ti}$ 粒子の空間分布は $\alpha-\mathrm{Al}$ 母相の塑性 流動に従うように変化した。すなわち，巨大ひずみ加工を施 した板状粒子を有する複相材料の粒子空間分布は母相の塑性 流動に依存する。

（3） $\mathrm{RT} て ゙ \mathrm{MDF}$ を施した $\mathrm{Al}-\mathrm{Al}_{3} \mathrm{Ti}$ 複相材料における $\mathrm{Al}_{3} \mathrm{Ti}$

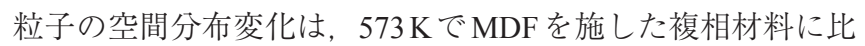
べて大きい。MDFにて微細化された $\mathrm{Al}_{3} \mathrm{Ti}$ 粒子は, $\alpha-\mathrm{Al}$ 母相 の塑性流動にて $\alpha-\mathrm{Al}$ 母相中を自由に移動することができる。

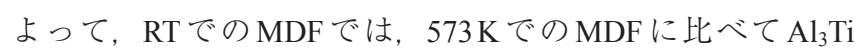
粒子がより微細になるため, 微細化された $\mathrm{Al}_{3} \mathrm{Ti}$ 粒子がより 広い領域に分散すると考えられる。つまり, 巨大ひずみ加工 を施した板状粒子を持つ複相材料中の粒子空間分布は加工温 度にも依存することがいえる。

（4） MDF に伴って $\mathrm{Al}^{-} \mathrm{Al}_{3} \mathrm{Ti}$ 複相材料の $\mathrm{Al}_{3} \mathrm{Ti}$ 粒子が破壊 し, かつ板状から粒状に変化する。したがって, $\mathrm{Al}-\mathrm{Al}_{3} \mathrm{Ti}$ 複 相材料をアルミニウム鋳造に扮ける結晶粒微細化剂としてと らえれば，MDFを施すことにより異質核の数密度増加と格 
子マッチングのよい面を創出することの同時達成の可能性が 考えられる。このように, MDFは結晶粒微細化剂の性能向 上にもつながる技術と考えられる。

謝 辞

本研究は, 公益財団法人軽金属奨学会の「研究補助 金」，国立研究開発法人新エネルギー・産業技術総合開発機 構（NEDO）の平成 28 年度「中堅・中小企業への橋渡し研究 開発促進事業」，およびの国立研究開発法人科学技術振興機 構（JST）の産学共創基礎基盤研究プログラム「革新的構造 用金属材料創製を目指したへテロ構造制御に基づく新指導原 理の構築」の支援を受けた。ここに謝意を表する。

\section{参 考 文 献}

1) R. Z. Valiev, R. K. Islamgaliev, N. F. Kuzmina: Scr. Mater., 40 (1999), 117-122, doi: 10.1016/S1359-6462(98)00398-4.

2) Y. Li and T. G. Langdon: J. Mater. Sci., 35 (2000), 1201-1204, doi: 10.1023/A: 1004740504619

3) C. Xu, M. Furukawa, Z. Horita and T. G. Langdon: Acta Mater., 51 (2003), 6139-6149, doi: 10.1016/S1359-6454(03)00433-6.

4) Z. Zhang, Y. Watanabe, I. S. Kim, X. Liu and X. Bian: Metall. Mater. Trans., A, 36A (2005), 837-844, doi: 10.1007/s11661-005-0197-x.

5) I. Sabirov, O. Kolednik and R. Pippan: Metall. Mater. Trans., A, 36A (2005), 2861-2870, doi: 10.1007/s11661-005-0281-2.

6) Z. Zhang, S. Hosoda, I. S. Kim and Y. Watanabe: Mater. Sci. Eng. A, 425 (2006), 55-63, doi: 10.1016/j.msea.2006.03.018.

7) Y. Watanabe, P. D. Sequeira, O. Sitdikov, H. Sato, Z. Zhang and I. S. Kim: Mater. Sci. Forum, 561-565 (2007), 251-254.

8) H. Sato, T. Murase, T. Fujii, S. Onaka, Y. Watanabe and M. Kato: Acta Mater., 56 (2008), 4549-4558, doi: 10.1016/j.actamat.2008.05.012

9）中山栄浩，宮崎徹也：軽金属，61（2011），729-735, doi: 10.2464 jilm.61.729.

10) H. Sato, T. Hishikawa, Y. Makino, T. Kunimine and Y. Watanabe: Proc. ICAA13, (2012), 1575-1580.

11) H. Sato, Y. Noda and Y. Watanabe: Mater. Trans., 54 (2013), 1274 1280, doi: 10.2320/matertrans.ME201306.

12) H. Sato, K. Ota, M. Furukawa, M. Azuma, Y. Watanabe, Z. Zhang and K. Tsuzaki: Mater. Trans., 54 (2013), 1554-1561, doi: 10.2320/ matertrans.MH201322.

13) R. Z. Valiev, A. P. Zhilyaev and T. G. Langdon: Bulk Nanostructured Materials: Fundamentals and Applications, John Wiley \& Sons, (2014), 239-288.
14) L. Köhler, K. Hockauf and T. Lampke: Metals, 5 (2015), 790-801, doi: 10.3390/met5020790.

$15)$ R. Z. Valiev, N. A. Krasiinikov and N. K. Tsenev: Mater. Sci. Eng. A, 137 (1991), 35-40, doi: 10.1016/0921-5093(91)90316-F.

16) M. Nemoto, Z. Horita, M. Furukawa and T. G. Langdon: Met. Mater., 4 (1998), 1181-1190, doi: 10.1007/BF03025992.

17) N. Hansen and R. F. Mehl: Metall. Mater. Trans., A, 32A (2001), 2917-2935, doi: 10.1007/s11661-001-0167-x.

18）堀田善治：軽金属，60（2010）, 134-141, doi: 10.2464/jilm.60.134.

19）辻 伸泰：軽金属, 62 (2012), 392-397, doi: 10.2464/jilm.62.392.

20) R. Kaibyshev, O. Sitdikov, A. Goloborodko and T. Sakai: Mater. Sci. Eng. A, 344 (2003), 348-356, doi: 10.1016/S0921-5093(02)00440-9.

21) O. Sitdikov, T. Sakai, A. Goloborodko, H. Miura and R. Kaibyshev: Mater. Trans., 45 (2004), 2232-2238, doi: 10.2320/matertrans.45.2232.

22) 中尾佳史, 三浦博已, 酒井 拓, 和田正彦：日本金属学会誌 70 (2006), 434-439, doi: 10.2320/jinstmet.70.434.

23) 酒井 拓, 三浦博已：まてりあ, 48 (2009), 491-498, doi: 10.2320/materia.48.491

24）森下正明：生理生態, 7 (1957), 134-144.

25) 石原外美, 塩沢和章, 宮尾嘉寿, 神島裕児：日本機械学会論文 集 (A 編)， 56 (1990)，494-500, doi: 10.1299/kikaia.56.494.

26）住田雅夫：繊維学会誌，51（1995），345-348, doi: 10.2115/fiber. 51.8 P 345 .

27）茂木徹一, 大野篤美：軽金属, 31（1981），415-421, doi: 10 . 2464/jilm.31.415.

28) T. B. Massalski, H. Okamoto, P. R. Subramanian and L. Kacprzak: Binary Alloy Phase Diagrams 2nd Ed., ASM International, 1 (1996), 225-227.

29) Y. Watanabe, H. Eryu and K. Matsuura: Acta Mater., 49 (2001), 775783, doi: 10.1016/S1359-6454(00)00384-0.

30) J. F. Nye: Acta Metall., 1 (1953), 153-162, doi: 10.1016/00016160(53)90054-6.

31) 東郷敬一郎：材料強度解析学一基礎から複合材料の強度解析ま で—, 内田老鶴戋，(2004），217-263.

32）渡辺義見, 佐藤 尚：軽金属, 64（2014）, 157-163, doi: 10.2464 jilm.64.157.

33) Y. Watanabe, T. Hamada and H. Sato: Jpn J. Appl. Phys., 55 (2016), 01AG01 (10 pages), doi: 10.7567/JJAP.55.01AG01.

34）渡辺義見, 平子孝明, 知場三周, 佐藤 尚：軽金属, 67（2017）, 208-213, doi: 10.2464/jilm.67.208.

35) Y. Watanabe, P. D. Sequeira, H. Sato, T. Inamura and H. Hosoda: Jpn J. Appl. Phys., 55(2016), 01AG03 (7 pages), doi: 10.7567/ JJAP.55.01AG03. 